\title{
O SUPREMO NA CONSTITUINTE E A CONSTITUINTE NO SUPREMO*
}

\author{
Andrei Koerner \\ Lígia Barros de Freitas
}

O presente artigo analisa as relações entre ministros do Supremo Tribunal Federal (STF) e outros agentes políticos durante o processo constituinte em duas perspectivas. A primeira delas considera o STF objeto da deliberação constitucional. Nesta, se enfocam projetos, embates e negociações políticas ao longo do processo constituinte e se determinam as posições e alianças com as quais foram definidas as características desse tribunal na nova Constituição. O STF é tomado, nesse sentido, como "produto" da deliberação constituinte e os ministros como agentes no processo no qual atuam - com o intuito de alcançar determinadas regras constitucionais acerca dos tribunais enquanto representantes institucionais do Poder Judiciário

\footnotetext{
* O presente artigo apresenta os resultados das pesquisas "Em busca do processo constituinte", coordenada por Cícero Araújo e Antônio Sérgio Carvalho Rocha, realizada no Cedec, com financiamento do CNPq, e "Pensamento jurídico, decisão judicial e processo político: uma análise política do controle da constitucionalidade nos anos de 1990", coordenada por Andrei Koerner, realizada no Ceipoc/ IFCH/Unicamp, com financiamento da Fapesp, CNPq e Faepex/Unicamp. Agradecemos a Celly Cook Inatomi, Carlos Eduardo Giungi Galvão, Ana Paula Brito Prata e Catarina Eichenberger pelo apoio no levantamento de dados.
} 
junto a outros agentes. A segunda perspectiva considera o STF como "produtor" da nova Constituição, pois, como jurisdição constitucional, tinha a capacidade de decidir sobre a forma, a dinâmica e os limites do processo constituinte. O STF incide sobre o processo de três modos: como recurso estratégico mobilizado pelos agentes para sustentar suas posições nos momentos críticos; como arena decisória que, ao decidir litígios, atua como instância normativa que fixa o significado jurídico dos conflitos políticos e, por fim, como instância legitimadora da atuação dos ministros como opinantes constitucionais. Em nome da instituição, eles enunciam juízos informais - sem qualquer processo judicial - acerca das controvérsias políticas, procurando determinar seu sentido jurídico-constitucional e assim orientar a direção do processo político.

Combinadas, essas perspectivas permitem verificar como o STF foi investido e projetado no processo cons142 tituinte e como seus ministros, em aliança com outros agentes, atuaram durante as deliberações, contribuindo desse modo para a orientação dos debates e das decisões na Constituinte. Assim, o artigo tem o objetivo de colaborar não só para a compreensão do sentido político dessa atuação dos ministros no processo constituinte, mas também do próprio resultado desse processo - em termos do formato institucional da jurisdição constitucional na Constituição de 1988 - e dos pressupostos implícitos à compreensão normativa que eles possuíam da Constituição de 1988. Para realizar esse propósito, a análise relaciona as posições dos ministros do STF às dos principais agentes políticos, procurando determinar suas alianças e conflitos ao longo do processo.

Foi elaborada a cronologia do processo constituinte e foram selecionados eventos críticos, tanto para a dinâmica interna da Constituinte como para as interações desta com outros agentes. Esses eventos foram pesquisados em bancos 
de notícias de jornais ${ }^{1}$, periódicos jurídicos ${ }^{2}$ e outras fontes secundárias ${ }^{3}$. Para determinar a confluência entre as posições dos ministros e juristas com as dos partidos e constituintes, foi feito o levantamento de suas manifestações (como discursos dos ministros e entrevistas) sobre os poderes da Constituinte e a organização das instituições judiciais ${ }^{4}$. As decisões da Assembleia Nacional Constituinte (ANC) sobre os poderes do STF tiveram como base os Anais da Constituinte e a documentação disponível nos sites da Câmara dos Deputados e Senado Federal ${ }^{5}$. As decisões sobre a Constituinte foram buscadas na página eletrônica do STF. Por fim, foi feito o levantamento das decisões sobre o STF nas principais etapas do processo constituinte, identificando-se as posições adotadas pelos partidos e relacionando-as com as posições destes a respeito do tema em outros momentos.

$\mathrm{O}$ artigo segue os momentos do processo constituinte, apresentando as duas perspectivas de análise em cada um

\footnotetext{
${ }^{1}$ As notícias de jornal citadas ao longo deste artigo foram levantadas em Sallum Júnior e Graeff (2004) e no Banco de Notícias do Senado Federal sobre a Constituinte (disponível em www2.senado.gov.br/bdsf/item/id/103421).

${ }^{2}$ Foram consultados: volume 28, número 4, da revista Convivium; o número 60-1 da Revista Brasileira de Estudos Políticos; o volume 24 da Revista da Procuradoria Geral do Estado de São Paulo; o número 21 da Revista do Advogado - com exceção deste último, que foi publicado em 1986, todos lançados em 1985.

${ }^{3}$ Tais como anais do IX Congresso Brasileiro dos Magistrados, realizado no Rio de Janeiro em 1982; do X Congresso Brasileiro dos Magistrados, realizado em Recife em 1986; do $6^{\circ}$ Congresso Nacional do Ministério Público, realizado em São Paulo em 1985; do I Encontro dos Presidentes de Tribunais de Justiça, realizado em Recife em 1985; do I Congresso Nacional de Advogados Pró-Constituinte, realizado em São Paulo em 1983 e do II Congresso Nacional de Advogados Pró-Constituinte, realizado em Brasília em 1985. Além destes, foram consultadas coletâneas tais como Chiarelli et al. (1985); Ministério da Justiça (1988); Machado e Torres Júnior (1997); Grinover et al., (1988) e Ribeiro (1985).

${ }^{4}$ Os discursos, entrevistas e artigos dos ministros do STF citados ao longo deste artigo estão disponíveis na seção Pasta dos Ministros, na página eletrônica www.stf. jus.br/portal/cms/verTexto.asp?servico=bibliotecaConsultaProdutoBibliotecaPas taMinistro

${ }^{5}$ As atas das reuniões das comissões estão disponíveis em <www.congresso.gov.br/ anc88/> e as atas das reuniões da Comissão de Sistematização de 09 de abril a 24 de novembro de 1987, em <www.senado.gov.br/publicacoes/anais/constituinte/ sistema.pdf $>$.
} 
deles. Nesses momentos, o STF e os ministros aparecem de maneiras distintas, em função das questões sobre as quais eles procuraram incidir.

\section{0 período pré-Constituinte}

No período que vai, grosso modo, de 1984 à instalação da Constituinte em 1987, o foco do conflito político está no sentido e no alcance das mudanças políticas a serem impressas pela Constituinte. Havia consenso entre os principais agentes políticos sobre os princípios gerais, as bases da organização política e o cerne dos direitos fundamentais na nova Constituição. Fazia parte desse consenso o fortalecimento das instituições judiciais ${ }^{6}$, com conteúdos precisos a respeito da independência financeira e administrativa do Poder Judiciário ${ }^{7}$, das garantias para o Ministério Público e da ampliação do acesso à Justiça.

Quanto às diferenças em relação à Constituinte, a pola144 rização se dava a respeito da natureza e poderes do Poder Constituinte: à direita falava-se em emendas ou revisão da Carta vigente e à esquerda defendia-se a Constituinte como assembleia soberana e exclusiva, em ruptura com a ordem existente. Acerca do Judiciário, a polarização se dava sobre as bases do constitucionalismo: as atribuições de controle da constitucionalidade e a participação popular nesse Poder. À direita, buscava-se preservar o STF, tribunal supremo com poderes concentrados de controle da constitucionalidade, e o Judiciário composto por uma magistratura profissio-

\footnotetext{
${ }^{6}$ Compreendidas num sentido amplo, que incluem não só o Poder Judiciário, mas também as demais organizações e agentes no processo judicial, assim como direitos e garantias constitucionais.

${ }^{7}$ A autonomia financeira seria a reserva de uma parcela do orçamento anual para o Judiciário, com a garantia de sua execução uniforme ao longo do ano ou, ao menos, a reserva ao Judiciário da iniciativa legislativa em matéria orçamentária; para a segunda, a exclusão do Executivo das nomeações e promoções dos juízes e o reconhecimento para que o Judiciário organizasse seus serviços, selecionasse e contratasse os demais funcionários.
} 
nal (Ferreira Filho, 1985a, 1985b; Reale, 1985a, 1985b). À esquerda, a proposição era de que as controvérsias sobre as leis fossem resolvidas pelo Legislativo, uma delegação deste ou um tribunal, e que houvesse ampla participação popular no Judiciário (Bisol, 1988; Castro, 1985; Comparato, 1986; Dallari, 1984; Grau, 1985) ${ }^{8}$.

À margem do debate constituinte, definia-se a mobilização corporativa dos juízes, liderada pelos dirigentes dos tribunais e que ultrapassava a direção institucional do STF na formulação de proposta para o Judiciário. No início dos anos de 1980, eles viam com reservas mudanças constitucionais mais profundas, mas a Constituinte apareceu como uma oportunidade para promoverem o fortalecimento do Judiciário, na qual reivindicavam voz e voto para os magistrados. Essa perspectiva se diferenciou, pois os dirigentes dos tribunais limitaram-se às questões corporativas, enquanto as associações de juízes ligaram-se às de outras profissões jurídicas e associações populares, e incorporaram demandas de centro-esquerda pela ampliação dos direitos e garantias ${ }^{9}$.

Os ministros do STF adotavam posições de centro às de direita ao encarar com reservas a Constituinte. Visavam preservar o STF de mudanças mais profundas e retomar a liderança que eles tinham perante os demais juízes ao promover as próprias demandas. Em fevereiro de 1985, falavam em "possíveis reformas constitucionais", com as quais os juízes deveriam colaborar junto às autoridades políticas, num "momento de reencontro do país com a plenitude

\footnotetext{
${ }^{8}$ Conforme depoimento de Dalmo Dallari em entrevista concedida em 09 de maio de 2008 e de Eros Roberto Grau em entrevista concedida em 12 de dezembro de 2008.

${ }^{9}$ A esse respeito ver as resoluções do $2^{\circ}$. Encontro dos Presidentes dos Tribunais de Justiça em Ribeiro (1985, pp. 59-63, 23-4). Ver também Chiarelli et al. (1985, pp. 19-20), Velloso (1985), a edição de 6 de outubro de 1985 de Folha de S. Paulo e os anais do IX Congresso Brasileiro dos Magistrados e do X Congresso Brasileiro dos Magistrados, já mencionados.
} 
do direito e com as aspirações democráticas" ${ }^{10}$. O novo presidente do STF, Moreira Alves, considerava o momento "delicado", pois o país ingressava em "nova fase política", na qual se apresentavam todo tipo de dificuldades, aspirações, expectativas. Ressaltava a excelência do STF e reafirmava a agenda das últimas décadas: o problema era a crise do STF causada pelo número excessivo de processos, contra o qual as reformas adotadas teriam resultado positivo. O STF tinha a visão integral do Judiciário, cujos problemas "não se enfrentam com diletantismos, muito menos com experimentações, jamais com os olhos postos no aplauso imediato"11.

Em maio de 1985, o ministro Oscar Corrêa considerava injustificada a Constituinte, pois não havia ruptura da ordem jurídica. Seria justificada apenas a reforma da Constituição, pois o problema central não era o texto, mas sim sua inexecução. A proposta de constituinte deveria 146 ser desmistificada, como um slogan com fins ideológicos e demagógicos (Corrêa, 1985, pp. 33, 49-56) ${ }^{12}$. O ministro Néri da Silveira adotava a perspectiva da continuidade ao lembrar que o STF poderia ser provocado para julgar a legitimidade jurídica da convocação da Constituinte. O Estado existente poderia se opor à elaboração de Constituição nova até esta que fosse promulgada, quando seria a completa desconstituição de todos os poderes constituídos (Ramos, 1985).

Os dirigentes políticos já mobilizavam o STF como recurso estratégico. No momento da promulgação da Emenda Constitucional n. 26 de 1985, convocatória da Assembleia Nacional Constituinte, Carlos Chiarelli, líder do PFL no

\footnotetext{
${ }^{10}$ Discurso proferido por Sydney Sanches em fevereiro de 1985.

${ }^{11}$ Discurso proferido por Moreira Alves em fevereiro de 1985.

${ }^{12}$ Naqueles meses de abril a julho de 1985, em diversas solenidades, ele proferiu discursos sobre a mudança do direito, a crise da Constituição, o STF e a Constituinte, que foram reunidos em volume (Corrêa, 1986).
} 
Senado, afirmava que recorreria ao STF se o Congresso não funcionasse junto com a ANC. O presidente Sarney entendia a questão da mesma forma ${ }^{13}$.

Nas sugestões que os ministros do STF enviaram à Comissão Afonso Arinos, estes defenderam a continuidade da forma de organização e atribuições do STF, mas também incorporaram as propostas dos magistrados pelo fortalecimento institucional do Poder Judiciário e outras alterações menos relevantes (Corrêa, 1987, pp. 149 e ss.).

O Anteprojeto Constitucional da Comissão Provisória de Estudos Constitucionais, a Comissão Afonso Arinos, publicado no Diário Oficial em 26 de setembro de 1986 adotava uma concepção comunitária de Constituição, com regime semipresidencialista e ampliação dos mecanismos de participação popular direta. A respeito das instituições judiciais, os dispositivos propostos por esse anteprojeto eram mais próximos da posição de "centro", pois eram contrários à ampliação da legitimidade ativa para as ações de controle direto da constitucionalidade, avançavam limitadamente no controle das omissões constitucionais e não ampliavam a participação popular no Judiciário. A respeito do STF, o anteprojeto mantinha tanto a posição institucional já ocupada pelo tribunal, quanto a forma de organização e as atribuições múltiplas deste, que detinha o controle concentrado e difuso de normas. Foi cogitada a criação de um tribunal constitucional, proposto de José Afonso da Silva, mas a Comissão afinal atendeu às demandas e pressões dos ministros do $\mathrm{STF}^{1415}$.

\footnotetext{
${ }^{13}$ Sobre o episódio, ver o relato de Flávio Bierrembach (1986), a análise de Rocha (2009) e a edição de 25 de novembro de 1985 de $O$ Globo.

${ }^{14}$ Entrevista concedida por Gisele Citadino em 22 de agosto de 2008.

${ }^{15} \mathrm{O}$ anteprojeto foi apelidado de "anteprojeto dos notáveis". A direita não criticou a organização da cúpula do Poder Judiciário, mas a regra da aplicação imediata dos direitos e garantias constitucionais e a inconstitucionalidade por omissão (artigo 10 e $\$ 1^{\circ}$ ), considerando-a confusas e contrárias aos princípios da legalidade e da separação dos poderes (Ferreira Filho, 1987, pp. 11-2; Prado, 1987, pp. 16-7). Para comentários mais favoráveis, Pereira (1987).
} 


\section{A Constituinte no STF}

Em apreciação geral sobre o processo constituinte, Adriano Pilatti afirma que os conservadores foram capazes de preservar suas posições intransigentes contra inovações, quando as decisões da ANG foram tensionadas por fortes agentes externos (Pilatti, 2008, p. 315). Ele exemplifica sua tese com a reforma agrária e a duração de cinco anos do mandato do presidente Sarney, aos quais podem ser acrescentados o papel das Forças Armadas e do STF. As pressões externas também foram importantes para a definição dos poderes e normas de funcionamento da ANC. Nos momentos críticos, os conservadores mobilizaram o STF como recurso estratégico, o qual foi invocado nos principais conflitos: a respeito das relações entre a Constituinte e os poderes constituídos; das regras internas da ANC e da duração do mandato do presidente Sarney.

148 A Constituinte e os poderes constituídos: 0 debate na instalação

Na sessão de instalação da ANC, o presidente do STF, Moreira Alves, adotou a perspectiva da continuidade, que vinculava juridicamente a Constituinte à ordem vigente. Aquele momento significaria "o termo final do período de transição com que, sem ruptura constitucional, e por via de conciliação, se encerra o ciclo revolucionário" (apud Paixão, 2012, p. 21) ${ }^{16}$.

Instalada a ANC, ocorreu o impasse sobre o Regimento Interno (Rianc), em que se punha a questão dos poderes da Constituinte em relação à ordem vigente. Em 4 de feve-

\footnotetext{
${ }^{16}$ A esse respeito, ver ainda a edição de 1‥ de fevereiro de 1987 de $O$ Estado de $S$. Paulo. Octavio Gallotti, em discurso proferido em março de 1987, referiu-se ao discurso de seu colega como "admirável oração, fadada a figurar, na história e nos anais do Parlamento, como notável contribuição do Poder Judiciário, conduzindo, no dia imediato, com segurança exemplar, os trabalhos da eleição da mesma augusta Assembleia, ora reunida".
} 
reiro de 1987, o deputado Maurílio Ferreira Lima (PMDB/ CE) apresentou o Projeto de Resolução n.1 de 1987 que previa a adoção pela Constituinte de resoluções constitucionais para alterar as normas vigentes, inclusive a duração do mandato do presidente Sarney, os decretos-lei, as medidas de emergência e o decurso de prazo. Contra a proposta, afirmava-se que os trabalhos constituintes eram limitados, pois a Constituinte fora convocada por emenda, sem ruptura na ordem constitucional, com a missão específica de elaborar a nova Constituição (Lopes, 2008, pp. 29-31). Para o Planalto, a proposta era "absolutamente ilegal”, pois entendia que era necessário respeitar o quórum qualificado e a votação para emendar a Constituição vigente ${ }^{17}$.

O STF foi mobilizado na controvérsia pela bancada do PL que, em 5 de fevereiro, encaminhou consulta ao STF para definir se os procedimentos vigentes de elaboração e reforma constitucional deveriam ser observados até a promulgação da nova Constituição. Segundo o deputado Álvaro Valle, a consulta visava obter a interpretação do STF dos limites da soberania da ANC. Por ser um procedimento inadequado, a consulta deveria ter sido arquivada pelo presidente do STF, Moreira Alves, mas ele a enviou para parecer da Procuradoria-Geral da República (PGR) com a recomendação de que fosse devolvida com urgência para a matéria ser examinada por aquele tribunal. O PL solicitou ao presidente da República que a PGR deveria encaminhar à apreciação judicial, com parecer favorável ou contrário, qualquer arguição de inconstitucionalidade. O procurador-geral já afirmara que a ANC teria poderes para interpretar a Constituição vigente, mas não para modificar seu texto ${ }^{18}$.

\footnotetext{
${ }^{17}$ A esse respeito, ver a edição de 5 de fevereiro de 1987 de O Jornal do Brasil.

${ }^{18}$ A esse respeito, ver as edições de 05 de fevereiro de 1987 de Jornal do Brasil e de Correio Braziliense; de 06 de fevereiro de 1987 de Folha de S. Paulo e do Jornal de Brasília e de 7 de fevereiro de 1987 de Correio Braziliense.
} 
O impasse foi contornado com a retirada do projeto por seu autor e a incorporação parcial de sua proposta ao preâmbulo do Rianc. A soberania da Constituinte foi afirmada, e ela poderia criar projetos de decisão para sobrestar medidas que pudessem ameaçar seus trabalhos, decisões. A soberania da ANC era defensiva; ela decidiria sem interferências externas, mas os projetos de decisão teriam caráter meramente reativo (Pilatti, 2008, pp. 41, 50-1; Lopes, 2008, pp. 33-4).

\section{A reforma do regimento}

A partir de agosto de 1987, os conservadores se unificaram em torno do Centrão para promover seus interesses. Apresentado o Projeto de Constituição A da Comissão de Sistematização (CS), atuaram para desqualificá-lo, provocar a reforma do regimento e apresentar um projeto de Constituição alternativo (Dreifuss, 1989; Zaverucha, 150 1994). Sarney procurou aprofundar a crise, ameaçando propor eleições gerais porque não aceitava a redução do seu mandato e a mudança do sistema de governo (Noblat, 1990, pp. 111-2). O consultor-geral, Saulo Ramos, afirmou no programa Crítica e Autocrítica da TV Bandeirantes que o poder constituinte da ANC era derivado e poderia ser controlado pelo $\mathrm{STF}^{19}$.

O Projeto de Constituição A da CS foi aprovado em 24 de novembro de 1987, mas até 27 de janeiro de 1988 as votações estiveram paralisadas pelas negociações sobre a reforma do Rianc, contra o qual o Centrão insuflara o ressentimento dos parlamentares ao taxá-lo como antidemocrático, porque eram necessários 280 votos para alterar o texto aprovado por 47 membros da CS. Ulysses Guimarães pretendia fazer a tramitação paralela dos títulos do Projeto A de Constituição na CS e em plenário, mas o iní-

\footnotetext{
${ }^{19}$ Conforme noticiado na edição de 16 de outubro de 1987 de Folha de S. Paulo.
} 
cio das votações inviabilizaria a alteração do Rianc. Com o apoio do presidente Sarney, os porta-vozes do Centrão ameaçaram recorrer ao STF contra a tramitação paralela, ou seja, caberia a esse tribunal decidir a controvérsia acerca dos trabalhos internos da ANC. Em 4 de novembro de 1987, Ulysses anunciou a desistência de seu intento e repeliu qualquer relação com a ameaça, pois esta não teria "qualquer fundamento jurídico, qualquer juiz de roça julgaria preliminarmente como inepta" a pretensão (apud Pilatti, 2008, p. 205) ${ }^{20}$.

\section{0 mandato do presidente Sarney}

A disputa a respeito da duração do mandato do presidente Sarney atravessa o processo constituinte e determina a aprovação do presidencialismo com mandato de cinco anos. Atores externos e internos à $\mathrm{ANC}$, regras presentes e futuras são inseparáveis no processo de decisão política. O STF está pareado às Forças Armadas, ministros e militares se completam como os braços legal e armado da manutenção da ordem e sustentação ao presidente, para bloquear avanços na elaboração da nova Constituição e projetar para o futuro a situação existente. Apresenta-se a seguir apenas o principal momento crítico: a votação em primeiro turno do sistema de governo e o mandato presidencial.

Em janeiro de 1988, começaram as votações em plenário em primeiro turno, com pressões externas intensas. Saulo Ramos reiterava que a ANC tinha poder constituinte derivado e não poderia desconstituir os poderes constituídos (Pilatti, 2008, pp. 233-5) ${ }^{21}$. Bernardo Cabral respondeu com um ensaio em que afirmava que a ruptura da ordem legal ocorreria com a promulgação da nova Constituição,

\footnotetext{
${ }^{20}$ A esse respeito, ver também edição de $1^{\circ}$. de dezembro de $O$ Globo.

${ }^{21}$ As teses foram publicadas em Ramos (1987).
} 
que superaria o vácuo de legitimidade popular criado pelo Golpe de 1964 (apud Paixão, 2012, pp. 26-7) ${ }^{22}$.

O presidente e seus aliados invocaram novamente o STF como parte das ameaças à ANC. Em 26 de fevereiro de 1988, no programa semanal Conversa ao Pé do Rádio, transmitido em cadeia nacional, ele advertiu contra supostas "minorias radicais" e era cogitada a possibilidade de ele defender seu mandato constitucional de seis anos junto ao STF. Para os analistas, as críticas à Constituinte compunham a vertente psicológica de um "golpe jurídico" em preparação. Depois da votação, o presidente recorreria ao STF com o argumento de que o Congresso Constituinte não tinha poderes para cortar seu mandato e os militares atuariam para proteger a decisão da mais alta instância judicial do país ${ }^{23}$.

Ainda em 26 de fevereiro, Sarney solicitou sua certidão de posse ao Senado, a qual poderia instruir seu pedido junto ao STF. Em 1․ de março, Jutahy Magalhães, primeiro152 -secretário do Senado, encaminhou a certidão ao Planalto que atestava que o presidente Jose Sarney tomou posse no dia 15 de janeiro de 1985 como vice-presidente de Tancredo Neves, ex-presidente da República, para um mandato de seis anos, amparado no artigo 77, parágrafo 1‥ da Constituição. Para o senador, a certidão seria documento suficiente para Sarney ingressar com ação no $\mathrm{STF}^{24}$.

Noutro movimento, o governo fortalecia seus apoios. Paulo Brossard, ministro da Justiça, buscou o apoio dos demais ministros; os quatro ministros militares apoiaram publicamente o presidencialismo com cinco anos. Outros ministros atuaram para fazer os governadores pressiona-

\footnotetext{
${ }^{22}$ Paixão sublinha o caráter inovador dessa ênfase na ruptura pelo resultado do processo constituinte: o termo "constituição [...] passou a significar, de forma mais forte, o início de uma ordem constitucional, a partir da ruptura com o ordenamento até então vigente, ao invés de manter-se no quadro semântico da transição, que parecia ser dominante no início dos trabalhos constituintes" (Paixão, 2012, p. 30).

${ }^{23}$ A esse respeito, ver a edição de 27 de fevereiro de 1988 de Folha de S. Paulo.

${ }^{24}$ Ver edição de 02 de março de 1988 de Jornal do Brasil.
} 
rem suas bancadas no Congresso (Dreifuss, 1989, p. 205) ${ }^{25}$. Cardoso Alves, depois de reunião com o presidente, declarava que este estava disposto a ir até as últimas consequências para garantir seu mandato de seis anos e que preparava o contra-ataque, inclusive com o recurso ao $\mathrm{STF}^{26}$. Antônio Carlos Magalhães alertava que as consequências de uma ação judicial convenceriam os descontentes com o mandato de cinco anos. Para o senador Jarbas Passarinho (PDS/PA), a disposição do presidente Sarney de recorrer ao STF revelava a falta de uma solução negociada, mas lembrava que "quando houver uma decisão do Supremo, as Forças Armadas serão obrigadas a mantê-la, já que têm responsabilidade pela ordem interna do país" 27.

Manoel G. Ferreira Filho afirmava que a Constituinte poderia mudar o mandato dos futuros presidentes, pois seus poderes não haviam sido restringidos pela Emenda Constitucional n. 26 de 1985, mas o STF poderia, até ficar pronta a nova Constituição, avaliar qualquer ato jurídico segundo a Constituição em vigor. Saulo Ramos tinha a mesma opinião e informava que o presidente Jose Sarney entendia que não era da competência da Constituinte definir a duração de seu mandato (Carvalho Filho, 1988) ${ }^{28}$.

Os constituintes reagiram às ameaças, considerando-as como parte de "uma escalada golpista" da Presidência. Ulysses Guimarães descartava a interferência do Judiciário sobre os trabalhos constitucionais e defendia a atuação dos constituintes, cujas decisões eram tomadas por maioria

\footnotetext{
${ }^{25}$ A esse respeito, ver as edições de 1‥ a 4 de março de 1988 de Folha de S. Paulo e de Gazeta Mercantil.

${ }^{26}$ Conforme noticiado na edição de 27 de fevereiro de 1988 de Folha de S. Paulo.

${ }^{27}$ Os comentários de Antônio Carlos Magalhães e Jarbas Passarinho podem ser encontrados nas edições de Folha de S. Paulo e Gazeta Mercantil de 27 de fevereiro de 1988.

${ }^{28}$ Outras menções à declaração de Saulo Ramos podem ser encontradas nas edições de 27 e 29 de fevereiro de 1988 de Folha de S. Paulo e de 28 do mesmo mês de Jornal do Brasil.
} 
absoluta. Ressaltava que "todos têm que respeitar a Constituinte", que estava "acima de todos os poderes, do Executivo e do Judiciário. [...] Ela [a Constituinte] está sob a guarda do Supremo, que existe para guardá-la, e não para estuprá-la”. Ele procurou o apoio dos governadores Waldir Pires (BA), Wellington Moreira Franco (RJ) e Pedro Ivo Campos (SC), lideranças da ANC, juristas e entidades da sociedade civil. Estes afirmavam que o recurso ao STF partia de uma "hipótese golpista", pois se supunha que uma eventual decisão favorável seria respaldada pelas Forças Armadas, com o argumento de que uma decisão da Justiça tem que ser respeitada ${ }^{29}$.

No plenário da ANC, circularam cópias de uma decisão unânime do STF, que teria decidido que o Congresso Constituinte tinha o caráter de “órgão instituído" e que poderia legislar apenas para o futuro. O deputado Amaral Netto (PDS/RJ) exibia a cópia da decisão no plenário 154 gritando "está aqui a garantia do mandato de seis anos para o presidente Sarney”, enquanto o deputado Cardoso Alves, em discurso afirmava que "o Poder Judiciário definiu que a Constituinte é órgão instituído”. Conforme noticia o jornal Folha de S. Paulo em 29 de fevereiro, o ministro do STF Djaci Falcão, relator do processo, desmentiu que o STF tivesse decidido sobre o caráter originário ou derivado da $\mathrm{ANC}$, ou que ele tivesse se manifestado sobre o assunto.

Às vésperas da votação, as ameaças de golpe tornaram-se explícitas. Elas foram feitas por auxiliares do presidente Sarney a parlamentares e empresários. Os ministros militares tomaram a iniciativa e advertiram o presidente da República e um elenco selecionado de lideranças políticas de

\footnotetext{
${ }^{29} \mathrm{~A}$ esse respeito, ver as edições de 27 e 29 de fevereiro, 1․ e 12 de março de 1988 da Folha de S. Paulo, as edições de 3 e 4 de março de $O$ Estado de S. Paulo, a edição de 27 de fevereiro de Gazeta Mercantil e as edições de 27 a 29 de março de Jornal do Brasil.
} 
suas intenções se o mandato de quatro anos fosse aprovado (Dreifuss, 1989, pp. 205-6; Noblat, 1990, pp. 137-46) ${ }^{30}$. Em 22 de março, a ANC, pela primeira vez com seus 559 membros presentes, aprova o presidencialismo com mandato de cinco anos, com 344 votos a favor, 212 contra e 3 abstenções (em junho, na votação dos Atos das Disposições Transitórias, o mandato de Sarney é convalidado com 328 a favor, 22 contra e 3 abstenções) (Pilatti, 2008, pp. 250-4). Enquanto Sarney elogiava as Forças Armadas, tornava-se evidente que os militares exerciam por conta própria a tutela sobre o processo político (Dreifuss, 1989, pp. 205-6; Noblat, 1990, pp. 143-4, 145-6; Zaverucha, 1994, p. 188) ${ }^{31}$.

Com a votação em primeiro turno, o problema da duração dos mandatos presidenciais estava encerrado, pois em segundo turno só caberiam emendas supressivas e a matéria não poderia ficar fora da futura Constituição. Em 2 de junho, na votação dos Atos das Disposições Transitórias, foi aprovada por 328 votos a 222, a duração de cinco anos para o mandato do presidente Sarney com expiração prevista para 15 de março de 1990, e com eleições diretas à Presidência da República em 15 de novembro de 1989 (Pilatti, 2008, p. 253).

Em toda essa movimentação, poucos consideravam que a crise era falsa. Ricardo Noblat previa que Sarney "[n]ão renunciará, não se suicidará e não será deposto e assim ir às últimas consequências significa apelar ao Exército". Para ele, Sarney não iria à Justiça por seu mandato, se fosse, não teria êxito e, se o tivesse, prevaleceria a decisão da Constituinte (Noblat, 1990, p. 136).

Seguramente, uma sentença do STF não seria condição necessária para um golpe militar, mas conferiria legitimidade constitucional à intervenção. Com a ameaça de uma ação no

\footnotetext{
${ }^{30}$ Esses acontecimentos foram noticiados em 26 de março de 1988 em Jornal do Brasil e em 05 do mês seguinte em $O$ Estado de $S$. Paulo.

${ }^{31}$ Sobre esse ponto, ver também a edição de 26 de março de 1988 de Jornal do Brasil.
} 
STF contra uma decisão da Constituinte, o governo antecipou sua intenção de extrapolar o conflito das negociações com as lideranças políticas. Independentemente do uso efetivo e do resultado que seria obtido, a provocação ao STF foi utilizada pelo presidente para afirmar sua pretensão de legitimidade constitucional e obter sustentação política.

Seria exagerado falar em "tutela judicial" exercida pelo STF sobre a ANC, mas o tribunal deu sinais favoráveis às teses conservadoras. Com exceção da resposta do ministro Djaci Falcão, os demais ministros mantiveram postura discreta ao longo da controvérsia e não se manifestaram como opinantes constitucionais, diferentemente do que fizeram a respeito de outras questões. De modo geral, a pesquisa em jornais não encontrou declarações públicas ou em off de ministros do STF que pusessem em questão a viabilidade ou a probabilidade de sucesso de um recurso ao tribunal contra decisão da Constituinte. Essa discrição 156 dos ministros do STF deixou em aberto as possibilidades de mobilização estratégica do tribunal, nas quais ele aparecia como uma arena decisória favorável a Sarney e aos conservadores. Como se verá a seguir, o STF não admitiu pedidos que se antecipavam à decisão da Constituinte, mas examinou o Rianc e limitou parcialmente seu campo de aplicação ${ }^{32}$.

Durante o processo constituinte as ameaças de recurso ao STF apareceram em outras ocasiões ${ }^{33}$. Porém, não alcançaram a mesma intensidade do que durante a votação no primeiro turno.

\footnotetext{
${ }^{32}$ Célio Borja, em entrevista concedida em 11 de dezembro de 2009, assegurou que o STF não acolhia as teses das limitações à soberania da Constituinte.

${ }^{33}$ No final das votações de primeiro turno, o círculo próximo a Sarney cogitava zerar os trabalhos da ANC ou suspender as votações por um mês (Dreifuss, 1989, p. 243). Conforme noticiou a edição de 19 de julho de 1988 do jornal O Estado de S. Paulo, Saulo Ramos sugeria suspender os trabalhos por uma ação no STF para declarar a inconstitucionalidade da Constituição como um todo, por ter a ANC desrespeitado as regras da Emenda Constitucional n. 26.
} 


\section{O STF como arena decisória: processos contra a ANC e seus membros}

Apesar das ameaças, as ações ingressadas e as decisões do STF foram pouco numerosas. No entanto elas trazem indicações importantes sobre a orientação normativa dos ministros, que poderiam ser elementos para a predição, pelos sujeitos, das decisões do tribunal. Os vínculos dos ministros com as lideranças políticas permitem algumas conjecturas a respeito da orientação deles em questões-chave como a do mandato do presidente Sarney.

A pesquisa na página eletrônica do STF gerou doze decisões relevantes ${ }^{34}$. Por um lado, ações contra decisões da mesa da Assembleia - quatro Mandados de Segurança (MS) e uma Petição (PET) - e, por outro, ações penais movidas contra ANCs por crimes contra a honra - cinco inquéritos (INQ) e uma ação penal (AP). Apresentam-se a seguir apenas as decisões relevantes para a análise.

Ações judiciais contra decisões da mesa da ANC

Nessas ações, os pedidos não foram acolhidos, pois o STF foi provocado antes da votação definitiva da ANC, ou da promulgação da Constituição. O MS 20.718 (relator Oscar Corrêa, decisão de 5 de agosto de 1987) foi proposto pelo prefeito de Nova Iguaçu, Paulo Antonio Leone Neto, con-

\footnotetext{
${ }^{34}$ Foi feita pesquisa na página de busca de jurisprudência do STF, com a palavra "Constituinte", para todos os tipos de processo e decisão no período de $01 \mathrm{de}$ fevereiro de 1985 a 05 de outubro de 1988. A busca gerou 25 resultados, dos quais: 6 em que "constituinte" era sinônimo de advogado; 2 recursos extraordinários referiam-se à Constituição de 1967 e 4 representações, à Constituições estaduais. Há um habeas corpus preventivo (HC 65.343/SP) da deputada Dirce Tutu Quadros ameaçada de internamento em estabelecimento psiquiátrico. A base de dados do STF inclui apenas decisões selecionadas e não retornou decisões monocráticas. Então, não se trata das decisões em todas as ações impetradas no STF contra a Constituinte. A Folha de S. Paulo refere-se a outros casos em 27 de fevereiro e em 12 de maio de 1988. As decisões do STF estão disponíveis na seção "Jurisprudência" da página eletrônica do STF:

<www.stf.jus.br/portal/jurisprudencia/pesquisarJurisprudencia.asp $>$.
} 
tra a mesa da ANC para evitar a redução do seu mandato de seis anos. Para o autor, como a comissão de poderes da ANC fixou em cinco anos o mandato de Sarney, ele temia que a decisão se estendesse aos prefeitos. $\mathrm{O}$ relator negou seguimento à ação e o pedido de reconsideração foi negado pelo plenário por unanimidade, porque se fundava em "pressupostos de fato e de direito inexistentes", que era o caso de uma norma do Projeto de Constituição.

O MS 20.828 (relator Sydney Sanches, dec. de 21 de setembro de 1988) foi proposto por Oswaldo Teixeira Luz contra o presidente da ANC, para obstar a discussão e votação do artigo 37 das disposições transitórias, sobre o pagamento de precatórios, com a alegação de que resultou de inadequada fusão de emendas, o que implicava prejuízo ao precatório a que tinha direito. A ação não foi conhecida porque o STF considerava que o autor não tinha direito líquido e certo a que a ANC interpretasse o regimento 158 do mesmo modo que ele. Além disso, como no caso do MS 20.718, a ANC ainda não havia aprovado o texto final. Porém, se ela efetivamente o fizesse, o autor poderia vir a invocar o fato no processo específico do precatório.

As decisões do STF nessas ações foram no sentido de não intervir nas decisões da $\mathrm{ANC}^{35}$. O STF afirmou que as votações da ANG não eram definitivas e que não existia ato da autoridade, pressuposto para conhecer o MS. Enfim, havia a jurisprudência antiga do STF de que não se admite a oposição de direito adquirido contra texto constitucional, fosse do Poder Constituinte originário ou derivado (por exemplo, o Recurso Extraordinário n. 94.414/SP).

\section{Licença prévia para processar membros da Constituinte}

Os INQs de n. 273 e 307 são relevantes para a determinação, pelo STF, do alcance das normas regimentais da ANC.

\footnotetext{
${ }^{35}$ Os outros casos foram: o MS 20.692, o MS 20.811 e a PET 254.
} 
Foi colocada a questão do alcance em face da Emenda Constitucional n. 1 de 17 de outubro de 1969, dos dispositivos do Rianc (Resolução n. 2 de 1987) referentes à inviolabilidade e à imunidade dos membros da ANC. O artigo 32 da EC n. 1/1969 estabelecia a inviolabilidade para os atos praticados no exercício de seus mandatos, com exceção dos crimes contra a honra. Sobre a imunidade processual, se o parlamentar fosse processado por crime comum, o processo poderia ser sustado por decisão da Casa do Congresso. O artigo $1^{\circ}$., parágrafo $2^{\circ}$. do Rianc estabelecia a inviolabilidade dos constituintes no exercício de suas funções, sem excepcionar os crimes contra a honra. A imunidade processual era a de que eles só poderiam ser processados criminalmente - em qualquer tipo de acusação criminal - ou presos com a licença da ANC, excetuadas as prisões em flagrante por crime inafiançável.

Nos INQ de n. 273 DF e 307 DF, constituintes foram denunciados no STF por atos praticados fora do exercício de suas funções e configuravam crimes contra a honra. O INQ de n. 273 DF foi iniciado por representação de um funcionário do Detran/RJ contra o deputado Brandão Monteiro (PDT) por este ter atribuído àquele atos de corrupção. $\mathrm{O}$ fato ocorreu em 3 de novembro de 1985, quando Monteiro era secretário de Transportes do estado e deputado federal afastado, eleito em legislatura anterior ${ }^{36}$. O INQ n. 307 DF foi iniciado por representação do ministro da Fazenda, Dilson Funaro, contra o deputado Amaral Netto, por este ter, em discurso na Câmara, feito declarações injuriosas atribuindo-lhe atos criminosos.

O PGR, Sepúlveda Pertence, suscitou nos dois casos a preliminar de que seria necessária a autorização da ANC para

\footnotetext{
${ }^{36}$ O INQ 273 DF contra o deputado Brandão Monteiro tornou-se Ação Penal (AP) n. 294, e a Câmara dos Deputados decidiu em 25 de fevereiro de 1988 sustar o processo, interrompendo a ação no STF (ver AP 294-QO RJ, relator Sydney Sanches, dec. de 09 de março de 1988).
} 
que fosse iniciado o processo. Seu parecer distinguia o caráter originário ou instituído da Constituinte da questão das franquias e extensão dos seus poderes. Segundo o PGR em parecer anexo ao inquérito, a ANG não era originária, pois não houvera ruptura na ordem jurídica vigente e foi convocada por emenda constitucional. A ANC, porém, era livre e soberana para elaborar a Constituição futura, era organizada num corpo unicameral, distinto e independente em relação ao Congresso, e tinha sua própria finalidade, com liberdade em relação aos órgãos constituídos; os representantes eleitos em 1986 receberam dois mandatos: o de parlamentares, membros do Congresso, para exercer suas funções legislativas ordinárias e o de constituintes, membros da ANC, para elaborar a nova Constituição. Ao elaborar o Rianc, prossegue o PGR, a ANC exerceu um poder distinto e necessário para atuar de modo livre e soberano, o que não era compreendido pelas normas da EC n. 1/1969, que não pre160 vira um órgão desse tipo para realizar a completa revisão da Constituição, ou seja, o Rianc não modificava as normas da Constituição, pois seu domínio não era compreendido por ela. Para o PGR, se os constituintes acusados não eram protegidos pela inviolabilidade tal como definida pela norma do Rianc, pois seus atos foram praticados fora do exercício de suas funções de constituintes e eram tipificáveis como crimes contra a honra, porém, eles eram protegidos pela imunidade processual, uma vez que o Rianc estabelecia a licença prévia para que os seus membros pudessem ser processados por crimes comuns, ao contrário do artigo 32. Por fim, concluía pela suspensão do processo e a demanda de autorização da ANC para processar os constituintes.

O parecer fazia o paralelo com a regra dos projetos de decisão do parágrafo 7ํ. do artigo 59 do Rianc, segundo o qual a ANC poderia votar projetos de decisão, destinados a "sobrestar medidas que possam ameaçar" seus trabalhos e decisões soberanas. A EC n. 26/1985 atribuiu à ANC os atri- 
butos de liberdade nas suas relações com os outros poderes do Estado e soberania na criação da futura Constituição. A liberdade da ANC inseriu-se no sistema constitucional em vigor e ela compreendia o próprio poder de criar instrumentos para garantir sua efetividade. $\mathrm{O}$ funcionamento concomitante do Congresso não subtraia da ANC o poder de se outorgar salvaguardas para sua liberdade, sendo que o exercício livre do mandato constituinte era protegido pela própria regra constitucional da EC n. 26/1985. Assim, reconhecia o caráter constituído e não originário da ANC, bem como sua soberania e liberdade, sem que suas decisões fossem subordinadas à revisão alguma.

Porém, os ministros do STF decidiram unanimemente em sentido oposto, rejeitando a preliminar suscitada pela PGR. O relator, Sydney Sanches, considerou que o Rianc não poderia eliminar a exceção dos crimes contra a honra estabelecida pela EC n. 1/1969 para a inviolabilidade dos parlamentares. Senão, "a norma regimental (interna corporis) estaria exorbitando de sua estrita e eventual esfera de incidência e operando em área, que se rege pela Constituição em vigor”. Esta estabelecia a exceção à inviolabilidade nos casos de crime contra a honra e não conferia imunidade processual aos deputados. Nos crimes contra a honra não era exigida licença prévia das casas do Congresso e " $[\mathrm{m}]$ enos ainda da Assembleia Nacional Constituinte, cujo dispositivo regimental só procura proteger o Constituinte no âmbito e no exercício do respectivo mandato".

O INQ n. 273 DF que fora devolvido pela PGR no dia 28 de outubro entrou em pauta e foi julgado no dia seguinte, na véspera da votação dos destaques sobre o sistema de governo e mandato presidencial pela comissão de sistematização $^{37}$.

\footnotetext{
${ }^{37}$ Os demais inquéritos foram julgados somente em 28 e 29 de setembro de 1988, depois da aprovação do texto final da Constituição (que ocorrera em 22 de setembro). São eles os INQ n. 284, n. 327, n. 350 e n. 353.
} 
A preliminar da PGR representava uma tentativa de fazer o STF se manifestar em sentido favorável aos poderes da ANC em face da EC n. 1/1969, mas a decisão do tribunal foi no sentido oposto. A PGR não defendia o caráter originário da ANC, mas sua soberania e liberdade. Porém, o STF considerou que esses atributos da ANC limitavam-se ao estabelecimento de suas próprias regras internas, à medida que, embora a ANC pudesse determiná-las, estas eram, por sua vez, enquadradas pelas normas da ordem constitucional vigente. Embora o STF não declarasse explicitamente, deixava aberto o campo para examinar e controlar os trabalhos da ANC e para determinar o alcance das mudanças criadas por esta em face dos poderes constituídos. A redução do mandato do presidente Sarney poderia vir a ser declarada pelo STF como uma extrapolação dos poderes da ANC.

Talvez fosse difícil o STF conceder liminar contra uma votação da ANC antes do encerramento do processo. Mas a maioria 162 dos ministros tinha orientação conservadora ou vínculos com o presidente Sarney. Oscar Corrêa, Célio Borja e Carlos Madeira tinham ligações pessoais e políticas com o presidente. Moreira Alves, Octavio Gallotti e Djaci Falcão expressaram teses de direita e contrariedade com os rumos da Constituinte. Sydney Sanches, liderança histórica dos magistrados, expressava reservas a respeito do processo. O presidente Rafael Mayer, Aldir Passarinho e Néri da Silveira, pareciam apostar no sucesso da Constituinte, embora os dois últimos fossem bastante reservados. Francisco Rezek, que também parecia apostar no sucesso, tinha vínculos com o ministro Leitão de $\mathrm{Abreu}^{38}$.

\section{O STF como objeto da deliberação constitucional}

Os ministros do STF foram importantes atores na Constituinte, construindo alianças com os parlamentares de cen-

\footnotetext{
${ }^{38}$ A esse respeito, ver a edição de 27 de fevereiro de 1988 de Folha de S. Paulo e de 4 de setembro de 1988 de Jornal do Brasil.
} 
tro e centro-direita, para que apoiassem a preservação do tribunal. A seguir, apresentam-se as decisões nas diversas fases de deliberação da ANC a respeito da estrutura do STF e os instrumentos para o controle da constitucionalidade de normas, especialmente os legitimados para proporem ação direta de inconstitucionalidade (por ação ou omissão) de norma legal ou Ato Normativo em Tese (ADI $)^{39}$.

Sobre a estrutura do STF, foram formuladas três propostas. Primeiro, a criação do tribunal constitucional ou tribunal das garantias constitucionais, que foi apresentada, discutida e aprovada em subcomissões diferentes com as mesmas linhas gerais: um tribunal autônomo com atribuições exclusivas sobre questões constitucionais, com ministros temporários, ou escolhidos pelo Congresso Nacional, ou pelos três poderes da República. Na subcomissão do Poder Judiciário e do Ministério Público, o tribunal constitucional foi defendido por Vivaldo Barbosa (PDT/RJ $)^{40}$, com base na proposta da $\mathrm{OAB}^{41}$. Na subcomissão dos direitos políticos, dos direitos coletivos e das garantias, o tribunal das garantias constitucionais foi proposto pelo relator Lysâneas Maciel (PDT/RJ) com base na ideia de José Paulo Bisol, relator da comissão da soberania e dos direitos e garantias do homem.

Uma segunda proposta era a criação no STF de uma seção especializada para conhecer as questões constitucionais, composta por ministros temporários. O STF manteria

\footnotetext{
${ }^{39}$ As informações desta seção são baseadas nas atas das comissões disponíveis na página eletrônica <www.congresso.gov.br/anc88/> e nas atas das reuniões da CS de 09 de abril a 24 de novembro de 1987 disponíveis na página eletrônica <www.senado.gov.br/publicacoes/anais/constituinte/sistema.pdf >, acesso em ago/2012.

${ }^{40} \mathrm{O}$ constituinte Vivaldo Barbosa não integrava a subcomissão do Poder Judiciário e do Ministério Público, mas sim a subcomissão do Poder Executivo e foi o primeiro vice-presidente da comissão da organização e sistema de governo. Entretanto, esteve presente na subcomissão estudada desde o início das atividades desta e apresentou emenda ao anteprojeto do relator, como será visto mais adiante.

${ }^{41}$ José Lamartine Côrrea de Oliveira, além de conselheiro federal da OAB, era professor titular de direito civil na Universidade Federal do Paraná.
} 
sua função unificadora da legislação federal, com ministros vitalícios. A proposta foi formulada pelos juízes paulistas da Apamagis e defendida na subcomissão por Michel Temer (PMDB/SP) e apoiada pelo presidente José Costa (PMDB/AL).

A terceira proposta era a continuidade do STF, que permaneceria como tribunal constitucional, federal e de cassação, com ministros vitalícios. A tese, defendida por Maurício Corrêa (PDT/DF), apoiava os posicionamentos do próprio STF, da AMB e do governo, expostos em audiência pública pelo ministro Sydney Sanches, pelo jurista Milton dos Santos Martins e pelo ministro da Justiça, Paulo Bossard.

Nas subcomissões e comissões da ANC, os resultados foram distintos. Na subcomissão dos direitos políticos, dos direitos coletivos e das garantias e na comissão da soberania e dos direitos e garantias do homem, a criação do tribunal das garantias constitucionais e a ampliação das garan164 tias constitucionais - notadamente o mandado de injunção - prevaleceram em todas as fases.

Por sua vez, na subcomissão do Poder Judiciário e do Ministério Público, as disputas políticas provocaram mudanças no curso das votações. O primeiro relatório e anteprojeto do relator, Plínio de Arruda Sampaio (PT/ $\mathrm{SP}$ ), adotou o tribunal constitucional, conforme a orientação de seu partido e da $\mathrm{OAB}^{42}$. Para ele, a ampliação dos direitos e garantias pela nova Constituição implicaria na criação de um tribunal constitucional cujos membros tivessem maior inserção política. O STF seria transformado em Tribunal Superior de Justiça e manteria suas outras

\footnotetext{
${ }^{42}$ A subcomissão era assessorada por um grupo de promotores e juízes de São Paulo, participantes de movimentos associativos (Maciel, 2002). Plínio de Arruda Sampaio, na entrevista que nos concedeu em 26 de setembro de 2008, relata os encontros promovidos por ministros do STF com membros da subcomissão. Eros Grau, na entrevista que nos concedeu em 12 de dezembro de 2008, analisou o significado político do insulamento institucional do Judiciário.
} 
atribuições. A proposta também era apoiada pelo líder do PMDB, Mário Covas (PMDB/SP).

Mas os outros membros da subcomissão não receberam bem a proposta. Apresentaram 28 emendas e as negociações levaram à adoção da formulação de Michel Temer (PMDB/SP): a criação de uma seção constitucional dentro do $\mathrm{STF}^{43}$. A seção seria formada por oito ministros, indicados em igual número pelo Executivo e Legislativo Federal. Haveria outros onze ministros vitalícios, indicados pelo presidente da República, dos quais ao menos quatro seriam magistrados. A subcomissão aprovou a proposta, derrotando as emendas pela manutenção do STF (14 votos a 5) ou a criação do tribunal constitucional (18 votos a 1 ).

O segundo tema polêmico na subcomissão foi o dos legitimados ativos para propor ADI perante o STF. O governo e o STF entendiam que deveria ser mantida a exclusividade do PGR. Em audiência pública, o ministro da Justiça, Paulo Bossard, alertou para os perigos de sobrecarregar o STF com o fácil acesso a uma ação sem custo. A OAB e a AMB defenderam a legitimidade para qualquer cidadão, bastando referir-se que era titular do direito. Mesmo constituintes favoráveis ao continuísmo do STF apoiaram a ampliação parcial da legitimidade ativa.

O relator Plínio de Arruda Sampaio incorporou a ampliação da legitimidade ativa para ADI nos seus anteprojetos. O primeiro anteprojeto elencou como legitimados o presidente da República, as mesas do Senado, da Câmara Federal, as assembleias legislativas, as câmaras municipais, os tribunais superiores e de justiça, os parti-

\footnotetext{
${ }^{43}$ Para Michel Temer, o acordo entre os que defendiam a permanência do STF e os que propunham o tribunal constitucional, manifestou-se no aumento do número dos ministros vitalícios. Dessa maneira, a seção seria formada por oito ministros, indicados em igual número pelo Executivo e Legislativo Federal. Haveria outros onze ministros vitalícios, indicados pelo presidente da República, dos quais ao menos quatro seriam magistrados (Brasil, 1987a).
} 
dos políticos registrados, o conselho federal da OAB e os promotores-gerais. No segundo, foi incorporada a emenda de Plínio Martins (PMDB/MS), que incluía os conselhos seccionais da OAB.

Outro importante instrumento para a eficácia dos direitos, o mandado de injunção, não entrou na pauta dessa subcomissão. A "arguição de relevância" nos recursos extraordinários, por meio do qual o STF exerce o controle de constitucionalidade difuso, foi criticada pela OAB pelo fato do exame desse pressuposto recursal ocorrer em sessões secretas. Mas não foi incluída no anteprojeto da subcomissão, por se entender que era matéria regimental do $\mathrm{STF}^{44}$.

Na comissão da organização dos poderes e sistema de governo foram aprovadas mudanças importantes no anteprojeto que consolidaram a combinação da continuidade quanto à estrutura do STF e a ampliação do acesso ao con166 trole direto da constitucionalidade de normas, proposta pela centro-esquerda.

No primeiro anteprojeto do relator Egídio Ferreira Lima (PMDB/SE), o STF voltou a ter a estrutura então vigente, sem seção especializada constitucional, composto por dezesseis ministros com mandato de doze anos, sem recondução. Também foram modificados os legitimados a proporem ADI, com o acréscimo do primeiro-ministro ${ }^{45} \mathrm{e}$ governadores, e com a exclusão da competência dos conselhos seccionais da OAB. O segundo anteprojeto do relator acrescentou as confederações sindicais. Com as votações dos destaques de emendas, o anteprojeto final da comissão rece-

\footnotetext{
${ }^{44} \mathrm{~A}$ discussão voltaria em pauta na reforma do judiciário, quando foi instituído, obrigatoriamente em sessões públicas e com julgamento motivado, o instituto de "repercussão geral".

${ }^{45}$ A figura do primeiro-ministro foi acrescida pelo fato de ter o anteprojeto escolhido o parlamentarismo como forma de governo. Essa comissão era a competente para tal matéria.
} 
beu mudanças importantes: os ministros do STF passaram a ser vitalícios e os tribunais superiores e tribunais de justiça foram excluídos dentre os legitimados ativos para a ADI.

Em audiência pública, participaram nessa comissão Márcio Thomaz Bastos, representando a OAB, e Sydney Sanches, representando o STF. Bastos mencionou o consenso entre os advogados a favor da criação da corte constitucional, do controle externo do Poder Judiciário e da motivação obrigatória das decisões judiciais, particularmente nas decisões do STF acerca da arguição de relevância nos recursos extraordinários $^{46}$. Como noticiou a Folha de S. Paulo em 15 de maio de 1987, Sydney Sanches defendeu a preservação das atribuições do tribunal, com a exclusividade do PGR para propor $\mathrm{ADI}^{47}$ entre outros pontos. Essas posições eram sustentadas publicamente por ministros e juristas, como Néri da Silveira e Leitão de Abreu ${ }^{48}$.

$\mathrm{Na}$ comissão de sistematização ${ }^{49}$, os dispositivos polêmicos do STF começaram a sofrer modificações, com negociações entre a direção da Constituinte e o $\mathrm{STF}^{50}$. O ministro Oscar Corrêa publica $O$ supremo tribunal federal, corte constitucional do Brasil, no qual atribuiu a proposta de criação da corte constitucional a críticas injustas ao STF. Fez também uma ameaça velada ao afirmar que os ministros eram discretos porque o STF "poderia vir a ter que dirimir" a controvérsia (Corrêa, 1987, p. VIII). Em 1 ${ }^{\circ}$. de setembro de 1987, o Jornal do Brasil noticiou que Antonio Marimoto pediu o aproveitamento de emenda com 39 mil assinaturas

\footnotetext{
${ }^{46}$ Essas manifestações de Bastos foram noticiadas na edição de 7 de maio de 1987 de Gazeta Mercantil e de 19 do mesmo mês de Folha de S. Paulo.

${ }^{47}$ Sydney Sanches relatou que o tema foi muito polêmico no STF e sua opinião particular era pela ampliação da legitimidade ativa para a ADI (Brasil, 1987b).

${ }^{48}$ Para essas posições, ver as edições de 16 de maio de 1987 de Gazeta Mercantile as de 19 do mesmo mês de Folha de $S$. Paulo e $O$ Globo.

${ }^{49} \mathrm{O}$ presidente desta comissão era Afonso Arinos (PFL/RJ) e o relator Bernardo Cabral (PMDB/AM).

${ }^{50}$ Essas negociações foram noticiadas em 10 de julho e 12 de agosto de 1987 em Folha de S. Paulo e em 24 de junho do mesmo ano em Correio Braziliense.
} 
para que entidades, assembleias legislativas e partidos políticos pudessem arguir inconstitucionalidade junto ao STF.

No primeiro substitutivo do relator (Cabral 1), o número de ministros do STF foi reduzido de 16 para 11, número mantido no segundo substitutivo (Cabral 2). O projeto Cabral 1 incluiu a avocatória, tema polêmico desde a Emenda Constitucional n. 7 de 13 de abril de 1977. Nelson Jobim (PMDB/RS) apresentou destaque para a eliminação do dispositivo, com o argumento de que se tratava de uma herança do regime militar que servira para que os ministros do STF, estes escolhidos pelos presidentes militares, controlassem a magistratura concursada. Michel Temer (PMDB/SP) acrescentou que a avocatória feria os princípios federativo e de autonomia do Judiciário, pois, por meio dela, o STF exercia um controle direto sobre os tribunais de justiça dos estados. O constituinte Paes Landim (PFL/PI) defendeu a avocatória, porque o PGR, 168 de cuja provocação ela dependeria, ganharia a posição de defensor da sociedade na nova Constituição. A emenda de eliminação da avocatória foi aprovada por 51 votos a 38 . No projeto Cabral 2, constaram pela primeira vez dispositivos acerca do mandado de injunção postos nos capítulos das garantias individuais e do Poder Judiciário. Foi reservada ao STF a competência originária nas matérias que competem ao presidente da República, a ambas as Casas do Congresso Nacional e outras autoridades federais.

A partir da vitória a respeito da organização do STF, os políticos e juristas conservadores passaram a combater outras propostas, como a de criação do STJ e do Conselho da Magistratura ${ }^{51}$.

Nas votações da comissão de sistematização tornaram-se mais claros os enfrentamentos políticos acerca da estrutu-

\footnotetext{
${ }^{51}$ A esse respeito, ver as edições de 9 de setembro e de 10 de outubro de 1987 de Jornal do Brasil e as de 06 e 17 de outubro de 1987 de Gazeta Mercantil.
} 
ra do STF. Os constituintes de centro-esquerda levantaram dois destaques de emendas. O primeiro, de Nelson Jobim (PMDB/RS), tinha o tribunal constitucional como modelo e propunha alterar a composição do STF para 16 membros, com mandato de oito anos: 5 indicados pelo presidente da República; 6 pela Câmara Federal e 5 pelo STF. Essas últimas vagas seriam reservadas aos magistrados de carreira ${ }^{52}$. O autor considerava necessários ministros temporários dado que o tribunal era responsável pelo controle concentrado e pelo controle difuso de constitucionalidade, enquanto os juízes vitalícios só o exerciam nos países, como os EUA, em que havia apenas o segundo tipo de controle. José Ignácio Ferreira (PMDB/ES) apontou o problema de recolocar os ministros após o fim do mandato, pois não seria razoável que voltassem a instâncias inferiores ou fossem postos em disponibilidade. A emenda foi rejeitada por 60 votos contra $3^{5354}$.

O segundo destaque, de Egídio Ferreira Lima (PMDB/PE), propôs o aumento do número de ministros para dezesseis. Paes Landim (PFL/PI) afirmou que não seriam necessários novos ministros, pois a criação do STJ reduziria as atribuições do STF. O número de ministros fora aumentado pelos militares com o propósito de manipular as decisões do STF. A emenda foi rejeitada por 56 votos contra 28 e 1 abstenção.

Sobre a competência do STF, houve mais três propostas. Apenas uma delas, a de Bonifácio de Andrada (PDS/

\footnotetext{
${ }^{52}$ Os projetos da comissão de sistematização dispunham que a escolha caberia ao presidente da República.

${ }^{53}$ Sobre esse ponto, ver as edições de 04 de novembro de 1987 de Folha de S. Paulo, Gazeta Mercantil, Jornal do Brasil e de O Estado de S. Paulo (deste último, ver ainda a edição do dia seguinte, 5 de novembro).

${ }^{54} \mathrm{O}$ constituinte Aluízio Campos (PMDB/PB) propôs emenda para a criação de um tribunal constitucional e a ampliação da legitimidade em ADI para associações comunitárias e pessoas individual ou coletivamente lesadas ou ameaçadas de lesão por ato ou omissão inconstitucional e por ADI preventiva. Mas a emenda não foi posta em votação porque a Presidência não admitiu a desistência parcial da proposta, solicitada por seu autor.
} 
MG), teve votação consensual. O destaque visava suprimir o parágrafo que atribuía ao STF a possibilidade de determinar o momento de perda de eficácia da norma em tese declarada inconstitucional, o que implicaria um retorno ao sistema vigente. A justificação era a separação dos Poderes e que a segurança jurídica seria ofendida se a declaração de nulidade fosse retroativa. Nelson Jobim (PMDB/ RS) e o relator apoiaram a emenda, que foi aprovada por 74 votos a 2 .

Dos destaques com votação polarizada, um deles foi de Nelson Jobim pela supressão da competência do STF para julgar recurso extraordinário de decisões do STJ, justificando-o pela necessidade de celeridade processual e porque, se fosse o caso, poderia ser usado o recurso extraordinário contra decisão que ofendesse a Constituição Federal. Egídio Ferreira Lima (PMDB/SE) e Paes Landim (PFL/PI) opuseram-se à emenda, por entenderem que ela afastaria do STF 170 as questões da federação. O destaque foi aprovado por 72 votos contra 19, contra o encaminhamento do relator. $\mathrm{O}$ outro destaque, proposto por Bonifácio de Andrada (PDS/ MG), fixava prazo para, nos casos reconhecidos pelo STF de inconstitucionalidade por omissão, a autoridade competente editar a norma necessária ${ }^{55}$. A emenda foi aprovada por 56 votos a 21 .

Os resultados das votações a respeito do Judiciário foram postos como exemplo pelo editor de $O$ Estado de $S$. Paulo, para quem a pressão da comunicação de massa sobre os parlamentares, "veiculando grande número de doutas opiniões favoráveis à manutenção do status quo vigente”, foi

\footnotetext{
${ }^{55} \mathrm{O}$ projeto Cabral 2 dispunha: "Declarada a inconstitucionalidade por omissão de medida para tornar efetiva a norma constitucional, será assinado prazo ao órgão do Poder competente para a adoção das providências necessárias". A emenda propunha: "Declarada a inconstitucionalidade por omissão de medida para tornar efetiva a norma constitucional, será dada ciência à Mesa do Poder competente para a adoção das providências necessárias e, em se tratando de órgão administrativo, para fazê-lo em 30 dias".
} 
a razão da vitória do STF na comissão de sistematização. O exemplo deveria ser copiado para outros temas: pressionar os representantes para mostrar-lhes que a opinião pública "espera deles a elaboração e a promulgação de uma Carta moderna", voltada ao futuro, mas "afeiçoada à índole e às tradições do povo a que se destina”. Ou seja, deveria implantar um regime que consagre a liberdade sem prejuízo da ordem ${ }^{56}$.

Em plenário, após acordo de lideranças ${ }^{57}$, foi aprovada a emenda substitutiva do "Centrão" sobre o Poder Judiciário, com 359 votos contra 10 e quatro abstenções. Essa emenda trouxe algumas mudanças em relação ao Projeto de Constituição "A”. Uma delas foi a necessidade de aprovação por maioria absoluta, no Senado Federal, do nome indicado para ministro do STF pelo presidente da República. A outra alteração foi o acréscimo das entidades de classe de âmbito federal como parte legitimada para a ADI. A emenda também trouxe de volta ao STF a avocatória.

Após a aprovação da emenda do Centrão, passou-se à votação, em primeiro turno, dos destaques de emendas e dos Destaques para Votação em Separado (DVS) ${ }^{58}$. Os destaques sobre o STF trataram de sua estrutura, da nomeação de seus ministros e de sua competência. Poucas dessas emendas tiveram acordo de lideranças para votação, diferentemente de outros temas (Pilatti, 2008; Freitas, 2012).

Sobre a estrutura do STF, foi votado o destaque proposto por Jorge Hage (PMDB/BA), Nelson Friedrich $(\mathrm{PMDB} / \mathrm{PR})$ e Anna Maria Rattes $(\mathrm{PMDB} / \mathrm{RJ})$ à emenda de Uldorico Pinto (PMDB/BA), que propunha um tri-

\footnotetext{
${ }^{56}$ As citações deste parágrafo foram retiradas do editorial da edição de 5 de novembro de 1987 de $O$ Estado de $S$. Paulo.

${ }^{57}$ Manifestaram-se nesse sentido: pelo PFL, Inocêncio Oliveira (PFL/PE); pelo PDT, Vivaldo Barbosa (PDT/RJ); pelo PMDB, Robson Marinho (PMDB/SP); pelo PTB, Gastone Righi (PTB/SP).

${ }^{58}$ Segundo o DVS, a matéria destacada, para permanecer no texto do projeto constitucional, deveria receber ao menos 280 votos.
} 
bunal constitucional, com 16 ministros, com mandato de oito anos: 2 indicados pelo Senado, 2 pela Câmara dos Deputados, 4 pelo Conselho Nacional da Magistratura, 2 pela $\mathrm{OAB}, 2$ pelo Ministério Público e 4 pelo chefe do Executivo. A emenda também propunha a suspensão de lei inconstitucional a partir de sua decretação pelo STF, mas foi rejeitada por 130 a $263 \operatorname{votos}^{59}$.

Sobre os requisitos para a nomeação dos ministros, foram votados dois destaques de emendas, ambos rejeitados. O primeiro, proposto por Nelson Jobim (PMDB/RS) e Artur da Távora (PMDB/RJ), à emenda proposta pelo primeiro, dispunha sobre a aprovação por dois terços do Senado Federal das indicações dos ministros do STF, não vitalícios, feitas pelo presidente da República, pela Câmara dos Deputados e pelo STF. A emenda foi rejeitada por 232 votos a 196 e três abstenções.

A respeito dos critérios de nomeação, o outro desta172 que de emenda proposto por Miro Teixeira (PMDB/RJ) à emenda de Plínio de Arruda Sampaio (PT/SP), propunha mandatos de doze anos para os ministros do STF, excluindo, pois, a vitaliciedade. Para Aloysio Chaves (PFL/ PA), que encaminhou contrariamente ao destaque, havia direta relação entre o sistema de governo e a vitaliciedade dos ministros da mais alta corte: em regimes presidencialistas havia a necessidade de um Poder Judiciário forte e com juízes vitalícios, garantia essencial da magistratura. A emenda, rejeitada, recebeu 229 votos contrários, 162 favoráveis e três abstenções.

Os destaques de emenda acerca da competência do STF foram em maior número: dos 5 destaques propostos, 2 tratavam de DVS: os de Plínio de Arruda Sampaio (PT/ SP), sobre a avocatória do STF, e o de Oscar Corrêa (PFL/

\footnotetext{
${ }^{59}$ Votação noticiada nas edições de 7 de abril de 1988 dos jornais Folha de S. Paulo, Gazeta Mercantil, Jornal do Brasil e O Estado de S. Paulo.
} 
$\mathrm{MG}$ ), que transferia a avocatória do STF para o STJ ${ }^{60}$, após ter sido derrubada a avocatória do STF. O DVS de Plínio Arruda Sampaio não obteve os 280 votos necessários para permanecer no texto, recebendo 249 votos a favor e 176 votos contrários e 5 abstenções. O DVS proposto por Oscar Côrrea, o qual teve encaminhamento contrário do relator, ou seja, no sentido de não passar a competência da avocatória do STJ para o STF, também foi rejeitado (por não alcançar 280 votos) com 255 votos contrários, 179 favoráveis e 12 abstenções.

Dos três destaques de emendas acerca da competência do STF, um deles era a fusão de emendas de Mário Lima (PMDB/BA), Paulo Pimentel (PFL/PR), Messias Góis (PF/SE), Ricardo Fiúza (PFL/PE), Walmor de Luca (PMDB/SC) e Paulo Ramos (PMDB/RJ). A fusão propunha suprimir o inciso que atribuía competência originária ao STF para a interpretação de lei ou ato federal e incluí-lo na competência originária do STJ. O destaque foi rejeitado. Outro, proposto por Maurício Corrêa, previa que o STF fixaria o momento que a lei declarada inconstitucional perderia eficácia. Foi rejeitado por 249 votos a 182. Somente o destaque de Jovanni Masini (PMDB/PR), para voltar inciso sobre a competência do STF, inserido no Projeto de Constituição "A” e ausente na emenda do Centrão, foi negociado entre as lideranças e aprovado por 338 votos contra 1 e 3 abstenções ${ }^{61}$.

No segundo turno, o Projeto de Constituição B foi aprovado por consenso, ressalvados os destaques. Só seriam

\footnotetext{
${ }^{60} \mathrm{O}$ artigo dizia: "Compete ao Superior Tribunal de Justiça: I - processar e julgar, originalmente: $[\ldots] \mathrm{g}$ ) as causas sujeitas a sua jurisdição, cuja avocação deferir, a pedido do Procurador-Geral da República, quando ocorrer imediato perigo de grave lesão à ordem, à saúde, à segurança ou às finanças públicas, para que sejam suspensos os efeitos da decisão proferida”.

${ }^{61} \mathrm{O}$ inciso dispunha sobre a competência originária do STF para "As causas e os conflitos entre a União e os Estados, a União e o Distrito Federal ou entre esses e outros inclusive as respectivas entidades da Administração direta".
} 
admitidas emendas supressivas ou corretivas, e a aprovação destas deveria contar com 280 votos. Mas os destaques foram previamente acordados, o que tornou as votações muito pouco polarizadas. Como noticiou o jornal Folha de S. Paulo em 26 de agosto, a avocatória foi suprimida, por consenso, com 350 votos a favor. O Projeto de Constituição C foi enviado para a comissão de redação e o texto final da Constituição foi aprovado em 22 de setembro de 1988, em turno único e votação global.

Desse modo, o substitutivo do Centrão aprovado em primeiro turno foi mantido pela rejeição das emendas de centro-esquerda que procuravam modificar a composição e as atribuições do STF. A supressão da avocatória foi a única modificação relevante introduzida pelas votações em plenário.

\section{Novas batalhas: o STF e a Constituição de 1988}

174 Às vésperas da promulgação, eram grandes as incertezas sobre a finalização dos trabalhos, os impactos das novas normas e a fidelidade dos dirigentes às inovações da nova Constituição. Os ministros do STF estavam no centro dessa incerteza, agentes da ordem constituída que participaram dos esforços para frear a Constituinte e que agora interpretariam o texto constitucional. Eles voltam a atuar como opinantes constitucionais, ao assumir o ponto de vista de juízes que examinam as dificuldades da aplicação do texto. Antes da aprovação do texto final, expressam suas opiniões em declarações à imprensa, seminários ${ }^{62}$ e eventos promovidos pelo próprio $\mathrm{STF}^{63}$.

\footnotetext{
${ }^{62} \mathrm{O}$ II $^{\circ}$. Fórum Jurídico "A Constituição Brasileira", foi realizado entre 19 e 21 de setembro de 1988 e organizado pela Federação do Comércio Minas Gerais, a Fundação Dom Cabral e a Academia Internacional de Direito e Economia (VVAA, 1988). Outro fórum jurídico foi organizado pelas mesmas entidades em 1989-1990 e publicado em [S.D.] (1990).

${ }^{63}$ Sessão de comemoração dos 160 anos do STF em 20 de setembro de 1988, publicada em Ministério da Justiça (1988).
} 
Políticos e juristas assumem duas atitudes contrapostas com relação à nova Constituição: de crítica, por conta dos efeitos desta sobre a governabilidade do país, ou de otimismo moderado quanto aos potenciais de sua aplicação. Pela tônica nos direitos sociais, nas regras a respeito da ordem econômica e nas novas garantias constitucionais, os críticos consideravam a nova Constituição inviável. Os constituintes teriam sido marcados pelo voluntarismo - inconsciente ou mal-intencionado -, ao tentar promover mudanças legais que produziriam inevitáveis efeitos perversos: a ineficácia do texto, conflitos sociais e a crise do Judiciário. A entrada em vigor da nova Constituição traria riscos para a segurança jurídica, devido ao "vácuo jurídico" criado pela revogação imediata das normas vigentes; sem as leis necessárias para dar eficácia às normas constitucionais, estas imporiam efeitos deficitários para orçamento público e custos econômicos para as empresas, o que trataria risco de queda dos investimentos e de conflito social, decorrente da frustração das expectativas da população alimentadas demagogicamente pelos constituintes (VVAA, 1988) ${ }^{64}$. Para Moreira Alves, a aplicação da Constituição traria "grandes problemas" ao país por ser "muito inovadora" e exigiria muito esforço do Judiciário para tornar o texto constitucional viável ${ }^{65}$.

Esses juristas conservadores exploravam as inconsistências do texto constitucional até que estas se tornassem contradições normativas, idealizações conceituais irrealistas ou problemas práticos insolúveis. Concluíam com prognósticos pessimistas sobre a nova ordem constitucional e, dada a descrença que tinham no Congresso, apostavam no trabalho dos juristas para resolver as dificuldades de interpretação ou "aparar as arestas" do texto, estimulando uma espécie de

\footnotetext{
${ }^{64} \mathrm{~A}$ esse respeito, ver as edições de 9 de agosto de 1988 dos jornais Folha de S. Paulo, Gazeta Mercantil, Jornal do Brasil e O Estado de S. Paulo.

${ }^{65}$ Conforme noticiado em 20 de setembro de 1988 pelas edições dos jornais Gazeta Mercantil e $O$ Estado de S. Paulo.
} 
revanche da razão jurídica contra o voluntarismo dos constituintes. Outra aposta era na remoção dos obstáculos pela revisão constitucional de 1993. Essas eram as análises de Ives Gandra, Celso Bastos, Oscar Corrêa e Moreira Alves no II $^{\circ}$. Fórum Jurídico de Belo Horizonte (VVAA, 1988) ${ }^{66}$.

A respeito do STF, Moreira Alves, Oscar Dias Corrêa e Djaci Falcão, adotando uma perspectiva de continuidade, retomavam a agenda anterior à Constituinte, a partir da qual viam como negativas as inovações, tanto no que foi criado quanto eliminado pela Constituição, e prognosticavam o aprofundamento da crise do tribunal (Ministério da Justiça, 1988).

Outros assumiam uma postura mais otimista. Para Rafael Mayer, presidente do STF, o trabalho dos constituintes tinha legitimidade e não havia "nada de tão exagerado que possa pôr em perigo um país"; o STF estava preparado para o aumento no volume de trabalho numa fase de reordenamento jurídico, na qual toda a legislação contrária à nova 176 Constituição seria revogada. Segundo ele, tratava-se de um fenômeno comum em todo o ordenamento que se inicia e, pois, não haveria propriamente "um vácuo" 67 .

A apreciação era compartilhada por Aldir Passarinho, Néri da Silveira e Francisco Rezek. Outros ministros eram menos claros. Célio Borja adotava a perspectiva da continuidade das duas ordens constitucionais. Esperava que, na apreciação das ações de inconstitucionalidade, o STF viesse a fazer uma interpretação mais constante e mais dinâmica da Constituição. A ampliação do acesso à ação direta de inconstitucionalidade permitiria isso, pois não se dependia mais da iniciativa do PGR. Haveria, então, maior presença político-constitucional do STF. Em seminários, Sydney Sanches apenas expunha os artigos da nova Constituição, sem

\footnotetext{
${ }^{66} \mathrm{~A}$ esse respeito, ver as edições de 9 de agosto de 1988 dos jornais, Folha de S. Paulo, Gazeta Mercantil, Jornal do Brasil e O Estado de S. Paulo.

${ }^{67}$ Declarações noticiadas nas edições de 16 de agosto, 2 e 10 de setembro de 1988 de Gazeta Mercantil e de 13 de agosto de 1988 de Folha de S. Paulo.
} 
comentários além da responsabilidade acrescida aos juízes ${ }^{68}$ (Carneiro, 1988; VVAA, 1988; Ministério da Justiça, 1988).

O otimismo moderado era compartilhado entre progressistas e liberais conservadores. Afonso Arinos (PFL/ RJ) refutava o argumento de que seriam necessárias leis ordinárias para a aplicação dos direitos individuais previstos na Constituição. Os ministros do STF saberiam retirar da Constituição os elementos necessários à eficácia desta (Carneiro, 1988) ${ }^{69}$.

Ministros do STF e juristas, conservadores ou progressistas, passavam a afirmar que dispositivos da Constituição não poderiam ter aplicação imediata, a depender de lei. Em primeiro lugar, estavam a fixação da taxa de juros em $12 \%$ e do valor do salário mínimo; o mandado de injunção; o habeas data e os instrumentos coletivos ${ }^{70}$.

Os ministros do STF fizeram reuniões reservadas com os dirigentes de outros tribunais para definir como aplicariam os dispositivos controvertidos ${ }^{71}$. Temiam uma avalanche de processos e as implicações de suas decisões. Em 6 de outubro, o STF decidiu que os mandados de injunção enviados à corte seriam aceitos, protocolados e distribuídos, mas ficariam parados à espera de lei do Congresso Nacional. Para os pedidos de habeas data, teriam como requisito a prova de que a informação foi solicitada e não foi fornecida pelo órgão competente. Em 19 de outubro, o STF indeferiu por

\footnotetext{
${ }^{68}$ Comentários noticiados na edição de 4 de outubro de 1988 de Jornal de Brasília. Não foram encontradas publicações de outros ministros, como Octavio Gallotti e Carlos Madeira, no período.

${ }^{69}$ Ver também a edição de 21 de setembro de 1988 de O Estado de S. Paulo.

${ }^{70}$ Conforme noticiado pelas edições de 20 de setembro de 1988 de Gazeta Mercantil e de $O$ Estado de S. Paulo.

${ }^{71}$ Um importante consenso dos ministros para a aplicação seletiva da Constituição era a propugnada "interpretação flexível" da competência do Senado para suspender a execução de normas declaradas inconstitucionais pelo STF, de modo a não compreender as decisões em ADI. Apesar de as proposições nesse sentido terem sido derrotadas na ANC, os ministros ressuscitavam decisão do STF no Processo Administrativo n. 4477, de 1972 (AMJ, 1988, pp. 28-9, 53-4).
} 
unanimidade a medida cautelar pedida pelo PDT contra o despacho presidencial, que aprovou parecer do consultor-geral da República, Saulo Ramos ${ }^{72}$.

Em aliança com os conservadores, ministros do STF e juízes foram bem-sucedidos em preservar o STF com muitos poderes concentrados e papéis institucionais acumulados, e em fortalecer o Poder Judiciário, acentuando seu insulamento institucional, sem controles ou participação externos. No pós-constituinte, os juízes passariam a inocular em seus julgamentos as inovações políticas e sociais trazidas pela nova Constituição. Julgavam segundo suas convicções, ao mesmo tempo que retribuíam os apoios recebidos, no momento que se iniciavam novas batalhas pela expansão e efetividade dos direitos.

178 Foram analisadas as relações entre ministros do STF e outros agentes políticos durante o processo constituinte em duas perspectivas: o STF como objeto das deliberações constitucionais e como instância normativa da ordem vigente, produtora do significado jurídico dos conflitos políticos sobre o processo constituinte.

No período anterior à instalação da ANC, o STF começou a ser utilizado como recurso estratégico por políticos de direita e centro-direita de modo a limitar as bases e o escopo da futura Constituinte. Os ministros do STF manifestaram suas opiniões sobre o tema em confluência com os políticos de centro à direita, ao apresentarem reservas ou críticas à mudança constitucional, enquanto cerravam

\footnotetext{
${ }^{72}$ A esse respeito, ver edições de 29 de setembro e 7 de outubro de 1988 de $G a$ zeta Mercantil; de 28 de setembro de 1988 de Correio Braziliense; de 4 de outubro de 1988 de $O$ Estado de S. Paulo; de 29 de setembro e 9 de outubro de 1988 de $O$ Globo; de 8 de outubro de 1988 de Jornal do Brasil e de 10 de outubro de 1988 de Folha de S. Paulo.
} 
suas fileiras para a manutenção do STF e o fortalecimento institucional do Judiciário.

Durante os trabalhos da ANC, o STF foi mobilizado pelos conservadores nos principais conflitos: a respeito das relações entre a Constituinte e os poderes constituídos; das regras internas da ANC e da duração do mandato do presidente Sarney. Os ministros do STF por vezes manifestaram-se como opinantes constitucionais a respeito de temas em discussão na ANC e tiveram intensa atuação junto aos constituintes como representantes institucionais do Poder Judiciário para evitar decisões desfavoráveis. Essa atuação foi em grande parte bem-sucedida, pois foi mantida a posição institucional do STF como cúpula do Poder Judiciário e como representante de um dos poderes da República, a forma de organização do tribunal, com ministros vitalícios, nomeados pelo presidente da República com aprovação do Senado e sem vagas reservadas aos juízes de carreira. Sobre suas atribuições, os ministros do STF tiveram sucesso parcial, por um lado, ao se manter a combinação de instrumentos de controle concentrado e de controle difuso da constitucionalidade de normas, com acesso parcialmente ampliado, e, ainda, a não previsão do controle concentrado da legalidade de atos do Executivo. Porém, contrariando a posição desses ministros e acolhendo as demandas de entidades e associações de juristas, a Constituinte decidiu pela criação do STJ com poderes de garantir leis federais e de uniformização da jurisprudência e pela eliminação dos principais instrumentos de concentração de poderes no tribunal, criados pelo regime militar: a avocatória, a interpretação de lei em tese, a arguição de relevância e o Conselho da Magistratura. Enfim, contrariando posições mais gerais entre os conservadores, ampliou a gama de direitos fundamentais e criou novas garantias para sua eficácia.

Nesse período, o STF foi provocado como arena decisória para se manifestar sobre os fundamentos constitucio- 
nais da Constituinte, em processos que tiveram os temas polêmicos como objeto e em ações contra decisões da Mesa da ANC. Outros casos foram dirigidos a temas correlatos, para cuja resolução o STF teria de se posicionar sobre as questões constitucionais fundamentais, como ocorreu em alguns casos contra a Mesa e nos processos movidos contra os membros da Constituinte. O STF se manteve unido nesses casos, pois, em decisões unânimes, evitou intervir nas decisões da Mesa da ANC, mantendo-se à distância das deliberações constitucionais. Porém, em processos contra constituintes, num caso de abertura de processo por crime contra a honra, o STF decidiu sobre o caráter derivado da Constituinte e afirmou seu poder de examinar as decisões da ANC. Essa decisão foi tomada num momento significativo, em que se iniciavam os embates na Comissão de Sistematização sobre o sistema de governo e a duração do mandato do presidente.

180 No final do processo constituinte, os ministros atuaram como opinantes constitucionais, uma parte deles aliada a conservadores que faziam prognósticos apocalípticos sobre os efeitos da nova Constituição e que estariam na linha de frente das reformas neoliberais nos anos seguintes. Outros ministros adotaram um otimismo moderado e os demais, uma atitude discreta. Mas concordavam com os conservadores sobre a não aplicação de algumas disposições constitucionais substantivas. No momento que antecede a promulgação da Constituição, o STF coordena sua ação com os dirigentes dos tribunais sobre a forma de interpretar os dispositivos polêmicos, como o mandado de injunção e o habeas data, limitando a sua eficácia imediata. Assim, sua pré-compreensão da Constituição de 1988 caracteriza-se pela perspectiva da continuidade política com o regime anterior, bem como a preocupação com a estabilidade social e a governabilidade diante dos novos direitos e garantias e da redefinição dos poderes governamentais. 
Enfim, a mobilização dos ministros para manter o STF tal como existia e para bloquear outras inovações na Constituinte pode ser entendida, por um lado, como parte da estratégia geral dos conservadores em manter intacta a estrutura institucional existente e, assim, assegurar que a ANC não ultrapassaria os limites de uma revisão constitucional. À medida que não houvesse a reorganização política fundamental dos poderes constituídos, o caráter derivado e limitado da Constituinte seria implicitamente confirmado. A preservação do STF era a da própria ordem constitucional moribunda de que era o intérprete supremo. Assim, a própria insistência dos ministros na manutenção institucional do STF expressava sua aliança com os conservadores. Por outro lado, o apoio dos conservadores à demanda dos ministros pela preservação do STF resultava da intenção destes de frear as mudanças na Constituinte e era a contrapartida ao apoio dos ministros à agenda que defendiam, especialmente no que concernia ao reiterado uso estratégico que faziam do STF para bloquear decisões que consideravam indesejáveis por parte da ANC.

A transição brasileira é marcada pela capacidade dos dirigentes do regime e os militares de limitarem o andamento e o alcance da redemocratização; pela permanência dos quadros do regime em instâncias decisórias cruciais do Estado e pela renovação da aliança entre aqueles, políticos conservadores e empresariado ao longo do processo. A Constituinte é um momento crucial na transição, no que se faz a ruptura simbólica ao se inaugurar uma nova ordem e ser inovadora em matéria de direitos e organização democrática do Estado, mas também carrega as marcas do conservadorismo e do autoritarismo político. Essa combinação está presente nas instituições judiciais, para a qual os juristas atuaram em aliança com todas as correntes políticas, enquanto os ministros do STF e dirigentes de tribunais aliaram-se com políticos de direita aos de centro. 


\section{Andrei Koerner}

é professor de ciência política na Unicamp, coordenador do GPD/Ceipoc e pesquisador do Cedec e do INCT/Ineu.

\section{Lígia Barros de Freitas}

é doutora em ciência política e pesquisadora do GPD/Ceipoc e do Datapol-UFSCar.

\section{Referências bibliográficas}

BIERREMBACH, F. 1986. Quem tem medo da constituinte. Rio de Janeiro: Paz e Terra.

BISOL, J. P. 1988. Uma questão de direitos. Brasília: Centro Gráfico do Senado Federal.

BRASIL. 1987a. "Ata da segunda audiência pública da comissão da organização dos poderes e sistemas de governo da assembleia nacional constituinte: subcomissão do poder judiciário e do ministério público, em 06 de maio de 1987". Disponível em <www.congresso.gov.br/anc88/>. Acesso em 3/11/2012.

1987b. "Ata da nona reunião ordinária da comissão da organização dos poderes e sistemas de governo da assembleia nacional constituinte, em 19 de maio de 1987”. Disponível em <www.congresso.gov.br/ anc88/>. Acesso em 10/11/2012.

CARNEIRO, L. O. 1988. "O poder 'constituinte' do Supremo". Jornal do Brasil, ano XCVIII, n.167, p.4.

CARVALHO FILHO, L. F. 1988. "Recurso ao judiciário é manobra política”. Folha de S. Paulo, ano 68, n.21514, 27 fev., p.A8.

CASTRO, A. E. et al. 1985. Política da constituinte. Porto Alegre: Mercado Aberto.

CHIARELLI, c. a. et al. 1985. O poder judiciário e a nova constituição. Porto Alegre: Ajuris.

COMPARATO, F. K. 1986. Muda Brasil! Uma constituição para o desenvolvimento democrático. São Paulo: Brasiliense.

CORRÊA, O. D. 1985. "A missão atual do supremo tribunal federal e a constituinte”. In: CHIARELLI, C. A. et al. O poder judiciário e a nova constituição. Porto Alegre: Ajuris, pp.23-56.

1986. A crise da Constituição, a constituinte e o Supremo Tribunal Federal. São Paulo: Editora Revista dos Tribunais.

1987. O Supremo Tribunal Federal, corte constitucional do Brasil. Rio de Janeiro: Forense.

DALLARI, D. 1984. Constituição e constituinte. São Paulo: Saraiva. 
DREIFUSS, R. A. 1989. O jogo da direita na nova república. Petrópolis: Vozes. FERREIRA FILHO, M. G. 1985a. "Nova perspectiva do processo constitucional”. Revista Brasileira de Estudos Políticos, n.60/61, pp.129-46. 1985b. "O estado de direito, o judiciário e a nova constituição". Convivium, v.28, n.4, pp.319-36.

1987. O anteprojeto dos notáveis. São Paulo: Saraiva.

FREITAS, L. B. 2012. A consolidação institucional do tribunal superior do trabalho (TST) na longa Constituinte (1987-2004). São Carlos, 372p. Tese de Doutorado. Departamento de Ciência Política da Universidade Federal de São Carlos.

GRAU, E. R. 1985. A constituinte e a constituição que teremos. São Paulo: Editora Revista dos Tribunais.

GRINOVER, A. P. et al. 1988. Problemas e reformas: subsídios para o debate constituinte. São Paulo: OAB-SP.

LOPES, J. A. V. 2008. A Carta da democracia: o processo constituinte da ordem pública de 1988. Rio de Janeiro: Topbooks.

MACIEL, D. A. 2002. Ministério público e sociedade: a gestão dos conflitos ambientais em São Paulo. São Paulo, 137p. Tese de doutorado. Departamento de Sociologia da Faculdade de Filosofia, Letras e Ciências Humanas da Universidade de São Paulo.

MACHADO, M. B. et al. 1997. Reforma Constitucional: ciclo de conferências realizado em 1985 na Casa de Rui Barbosa. Rio de Janeiro: Casa de Rui Barbosa.

MINISTÉRIO DA JUSTIÇA. 1988. "Sessão Especial: 160 Anos do Supremo Tribunal Federal”. Arquivos, v.41, n.73.

NOBLAT, R. 1990. Céu dos favoritos: o Brasil de Sarney e Collor. Rio de Janeiro: Rio Fundo.

PAIXÃO, C. 2012. "A constituição em disputa: transição ou ruptura". Comunicação apresentada no Seminário Direito e Linguagem na Construção do Estado Brasileiro do Programa de Pós-Graduação em Direito da USFC. Florianópolis.

PEREIRA, O. D. 1987. Constituinte: anteprojeto da Comissão Afonso Arinos. Brasília: UnB

PILATTI, A. 2008. A constituição de 1987-1988: progressistas, conservadores, ordem econômica e regras do jogo. Rio de Janeiro: Lumen Juris.

PRADO, N. 1987. Os notáveis erros dos notáveis. Rio de Janeiro: Forense.

RAMOS, S. J. 1985 "Pó de mico na democracia". Jornal do Brasil, ano XCV, n.64, 11 jun., p.11.

1987. Assembleia constituinte: o que pode; o que não pode - natureza, extensão e limitação de seus poderes. Rio de Janeiro: Alhambra. 
REALE, M. 1985a. "Como deverá ser a nova constituição". Revista Brasileira de Estudos Políticos, n.60-1, pp.9-24. 1985b. "Consciência constitucional". Convivium, v.28, n.4, pp.281-5.

RIBEIRO, B. S. 1985. O poder judiciário e a futura constituição federal: documentos do II Encontro dos Presidentes de Tribunais de Justiça. Recife: Apipucos.

ROCHA, A. S. C. 2009. "A era constituinte no Brasil, 1971-2008: forças políticas, momentos críticos e construção institucional”. Trabalho apresentado no Seminário Em Busca do Processo Constituinte. São Carlos, UFSCar.

[S.A]. 1990. A nova ordem constitucional: aspectos polêmicos. Rio de Janeiro: Forense.

SALLUM JÚNIOR, B. J.; GRAEFF, E. P. (orgs.). 2004. "Poli: eventos da política nacional, 1987-1995" [Banco de dados]. Disponível em <www.cis. org.br>. Acesso em 11/11/2012.

VVAA. 1988. A Constituição brasileira de 1988: interpretações. Rio de Janeiro: Forense Universitária.

VELLOSO, C. 1985. "O poder judiciário na nova constituição: uma proposta de reforma”. In: CHIARELLI, C. A. et al. O poder judiciário e a nova constituição. Porto Alegre: Ajuris, pp.131-62.

ZAVERUCHA, J. 1994. Rumor de sabres. São Paulo: Ática. 